\title{
Virumaa rahvaluule kogumine ja kogujad ${ }^{1}$
}

\begin{abstract}
Anu Korb
Teesid: Artiklis tutvustatakse Eesti rahvaluule kogumist läbi aegade ühe piirkonna - Virumaa rahvaluulekogujate tegevuse abil. Rahvaluule kogumine sai alguse saksa soost haritlaste harrastustest 19. sajandi algupoolel ja kasvas 19. sajandi lõpukümnenditel Jakob Hurda, Matthias Johann Eiseni jt initsiatiivil ülemaaliseks ärksaid inimesi kaasavaks ettevõtmiseks. Riigikorrast ja vahepealsetest keerulistest aegadest sõltumata on Eestis järjepidevalt kogutud rahvapärimust professionaalide ja vabatahtlike kaastööliste koostööna.
\end{abstract}

Märksõnad: Jakob Hurt, kogumisüleskutsed, rahvaluulekogujad, rahvaluule kogumine, Virumaa

\section{Esimesed rahvaluule kogujad}

Eesti rahvaluule kogumine sai alguse saksa soost haritlaste Johann Heinrich Rosenplänteri (1782-1846) jt harrastustest 19. sajandi algupoolel (Mälk 1963: 18-19). Rosenplänteri kaastööliste seas paistis eriti silma Kadrina pastor Arnold Friedrich Johann Knüpffer (1777-1843), kes 19. sajandi esimesel poolel pani rahvasuust kirja üle 600 laulu (Tedre 1974: 79). Need Kadrina rahvalaulude kirjapanekud on tallel Eestimaa Kirjandusliku Ühingu (EKÜ) rahvaluulekogus. Mõned Virumaa rahvaviisid noodistas 1877. aastal soomlane Akseli Aukusti Borenius-Lähteenkorva.

Esimesed eesti soost rahvaluulekogujad olid Friedrich Robert Faehlmann (snd Rakke lähedal Ao mõisavalitseja pojana) ja Friedrich Reinhold Kreutzwald (snd Kadrina lähistel Jõepere mõisas), mõlemad osalesid Õpetatud Eesti Seltsi (ÕES) tegevuses. Folkloori käsitasid nad rahvusliku kirjanduse loomuliku alusena. Faehlmann avaldas muistendeid Õpetatud Eesti Seltsi toimetuste sarjas. Kreutzwald arendas Faehlmanni tegevust edasi, tulemuseks oli Eesti rahvuseepose "Kalevipoeg" valmimine. 1860. aastatel pöördus Kreutzwald kirjutistega rahvaluule tähtsusest ja väärtusest ka eestlaste endi poole (Laugaste 1952). 
Varasematest rahvapärimuse kogujatest väärib tähelepanu veel keeleteadlane Mihkel Veske. Oma noorpõlves, 1875. aasta suvel tegi ta Tartu Ülikooli rahalisel toel esimese kogumismatka Virumaale. Põhieesmärgiks oli keeleainestiku kogumine, kuid välitööl pani ta kirja ka 250 Virumaa laulu. Vanu regivärsilisi rahvalaule hindas $M$. Veske eeskätt vanade keelevormide tõttu. 1876. aastal tegi ta teise reisi Virumaale, kogudes Simuna, Lüganuse, ViruJaagupi, Haljala ja Väike-Maarja kihelkonna pärimust (Mirov 2009: 61). Veske avaldas Virumaa laule Eesti Kirjameeste Seltsi toimetiste väljaandena "Eesti rahva laulud" - I vihk 1879. a ja II vihk 1883. a (Tedre 1974: 82).

\section{Jakob Hurt rahvaluule suurkogumise organiseerijana}

Rahvaluule suurkogumise organiseerimiseni jõudis 1870. aastatel Jakob Hurt (eluaastad 1839-1907). Aastatel 1872-1881 tegi ta seda tööd Eesti Kirjameeste Seltsi presidendina ning jätkas ka pärast presidendi ametist taandumist. Oma esimeses avalikus üleskutses "Palve neile, kes jutustusi isamaa sündinud asjost armastavad" (1871) kutsus Hurt koguma rahva mälestusi ning selgitavas kirjutises "Mis lugu rahva mälestustest pidada" avas kogumisteemad laiemalt kui see oleks hõlmatav klassikaliste rahvaluuleliikidega (Hurt 1989: 9-10, 26-28; Hiiemäe 1989: 310). Mõned Väike-Maarja laulud on tema enda kogutud. Esimeste hulgas saatsid Hurdale Virumaa materjali R. Neus ja Joosep Robert Rezold Kadrinast, Hans Krickmann (Krikmann) Viru-Nigulast ning Jakob Martin Sommer Viru-Jaagupist.

1888. aastal, mil J. Hurt ajalehtedes Olevik ja Postimees oma kuulsa üleskutse "Paar palvid Eesti ärksamaile poegadele ja tütardele" avaldas, vastas talle 33 virumaalast. Oma esimeses aruandes 24. märtsil 1888 tänas Hurt nelja meest sisuka saadetise eest, üks neist oli Nikolai Heek Vaivarast. Samas märkis ta, et Virumaal on laule hästi kogutud Väike-Maarjas, Viru-Jaagupis ja Viru-Nigulas, varasemast ajast tõstis ta esile Kadrina pastor Knüpfferi korjanduse. Kogumistöös mahajäänud kihelkondade nimistusse paigutas ta aga Lüganuse, Jõhvi, Iisaku, Rakvere, Haljala ja Vaivara. Oma kogumisüleskutses õhutas Hurt nende kihelkondade rahvast, kust oli seni vähe materjali laekunud, aktiivsemalt kaasa lööma, sest needki kihelkonnad ei või ommeti tuima tunnistuse ja kurva mälestuse alla jääda järeltuleva põlvedele (Hurt 1989: 49).

Jakob Hurt püüdis kogumistööd ka otse suunata, saates ühe oma parematest kaastöölistest, Vastseliina kihelkonnast pärit Hindrik Prantsu Alutagusele korjamisreisile. H. Prants, kes 1888. aastal töötas peamiselt Simuna ja Lüganuse kihelkonnas, hindas oma tööd võõras murdepiirkonnas ja ümbruses üsna kriitiliselt: 
Palju vaevasem on säält vanavara saamine kui setude seast, ja mis saadaval, on paljad riismed. Minu korjanduses ei tohi ma ühtegi laulu täieliseks kiita, kõik on lühikesed otsukesed, sana siit, teine säält. (RPS II, 9: 76.)

Põhiliseks takistuseks H. Prantsu pärimusekogumisel Alutagusel sai asjaolu, et ta ei tundnud kohalikku murdekeelt ega Virumaa rahvalaule.

Märksa tulemuslikumaks osutus samal 1888. aasta suvel üliõpilaste-stipendiaatide - Eesti Üliõpilaste Seltsi (EÜS) liikmete Mihkel Ostrovi ja Oskar Kallase kogumistöö Jõhvi, Vaivara ja Lüganuse kihelkondades. Noored mehed püüdsid laulud kirja panna peamiselt laulmise järele: laulu lasti korrata mitu korda, mõnikord kirjutas üks korjaja üles ühe, teine teise rea. Ostrovi ja Kallase saak sel kogumisreisil oli 851 rahvalaulu ja 53 punkti uskumusi-kombestikukirjeldusi, enim kirjapanekuid tõid nad Jõhvi kihelkonnast (RPS I, 5: 161). Oma 10. aruandes kiitis Jakob Hurt noormehi:

Laulude kogu ei ole mitte üksnes väljastpidi suur ja paks, vaid ka seestpidi väga tuumakas ja tähtis, nii hästi keele poolest kui muinasaja uurijale. See töö on tõesti suurekooli õppijate vääriline ja meie paneme tema kõigile tõisile universiteedi jüngritele kui hiilgava eeskuju silmade ette, kuidas óppimise vaheaega suve pitkil päevil kadumata kasuga võib pruukida. (Olevik 1888, nr 37.)

M. Ostrov ja O. Kallas suutsid kogumistööle ärgitada ka Toila kooliõpetaja J. Linksteini, kes Kallasele ja Ostrovile antud lubaduse täitmiseks pani kaasõpetajate abiga kirja 110 regilaulu.

J. Hurda 1888. aasta kogumisüleskutse leidis rahva seas elavat vastukaja. Paljud rahvaluulekogujad lähtusid esimesest entusiasmipuhangust. Nt piirdusid Hurda kaastöölistest Jõhvis-Iisakus (18) ligi pooled (8) ühekordse saadetisega (Tedre 1999: 91). Kui kogumine hakkas rohkem tööd ja aega nõudma, jäädi kõrvale. Ometi oli ka neid, kes saatsid pärimusmaterjali korduvalt ning pikema aja vältel.

Innustunud kaastöölisi leidus rohkesti õpilaste ja üliõpilaste seas. Haljala khk Vihula vallas sündinud Karl Johannes Leetberg, hiljem keeleteadlane, kogus rahvaluulet gümnaasiumis õppimise ajal ja üliõpilasena. Kristjan Raud tegi oma kunstiõpingute vaheaegadel kirjapanekuid kodumail Viru-Jaagupis, Rakvere ümbruses ja Simunas. Viru-Jaagupi rahvalauliku Jüri Klammeri tekstide juurde visandas ta ka lauliku portree (Kõiva 1985: 29). Teoloogiaüliõpilane Jakob Valk saatis Hurdale Viru-Nigula vanu laule. Tudulinnas sündinud, hiljem Lüganuse kihelkonnas elanud Emilie Bachmann kogus rahvaluulet neiupõlves. Tema isa pidas Purtse-Liiva kõrtsi ning see asjaolu hõlbustas rahvapärimuse talletamist. Neiu saatis Hurdale rahvauskumuste ja kommete kirjeldusi, rahvajutte ja -laule. 
Kogumistöö eestvedajatena kohapeal väärivad tunnustust koolmeistrid. Oonurme kooliõpetaja Abel Valter kogus mitmekesist materjali Iisakust, Viru-Jaagupi rahvaluulet kogus kooliõpetaja J. Uustallo (Uustalu). Vasavere kooliõpetaja August Tõnorist (Tõnurist), sündinud vabadiku peres Mäetaguse vallas, läkitas ajavahemikul 1888-1892 J. Hurdale 12 saadetist Jõhvi piirkonnast. Johann Petrovitsch, kes õppis Kohtla külakoolis ja Jõhvi kihelkonnakoolis ning oli abiõpetaja Purtse koolis, saatis Hurdale heas murdekeeles Jõhvi ning Lüganuse pärimusmaterjali. Kihelkonnakooli juhataja Heinrich Masing innustus Hurda algatusest niivõrd, et kogus ise rahvaluulet ning õhutas sellele tööle oma õpilasi. Ta on saatnud Hurdale ka oma õpilaste kogutut. Nii oli Vaivara kihelkonnas Hurdal kaastöölisi märksa enam kui lähipiirkonnas Jõhvis ja Iisakus. Köstrikooli juhataja Theodor Hansen Iisakust pole ise Hurdale rahvaluulematerjali saatnud, kuid oskas oma õpilasi kogumistööle suunata. Kooliõpetaja Konrad Roost kogus pärimusainest Haljala kihelkonnast.

Hurda kaastööliste seas oli ka talunikke, käsitöölisi, kaupmehi, töölisi jm elualade esindajaid. Lesknaine Miina Russmann kogus materjali Narvast. Jaagup Thomson (Tomson), kes sündis Lüganuse kihelkonnas Püssi mõisas, kus ta isa oli kubjas ja hiljem öövaht, saatis Hurdale aastatel 1892-1897 oma isalt kuuldud regilaule. Talunik Nigolas Otto läkitas Hurdale materjali ajavahemikus 1890-1896 neljal korral, vahepeal saatis ta oma kirjapanekuid ka Matthias Johann Eisenile. Jõhvi piirkonnas kirjakandjana tegutsenud Juhan Lilienbach, hiljem proletaarne luuletaja ja kirjastaja, pani rahvasuust kirja sadu lehekülgi pärimusainest. Jõhvi kihelkonnas sündinud Mihkel Eljas (Elias) teenis elatist esmalt rändkaupmehena. Tema töö eeldas tihedat suhtlemist rahvaga ning ta tundis elavat huvi rahvapärimuse vastu. Oma rändkaupmehe-põlves püüdnud ta nimelt öömajale jääda kohtades, kus leidus laulikuid, jutustajaid ja rahvatarkuse teadjaid. Hiljem pidas Eljas Pühajõel talurahvakauplust, seejärel oli kauplusepidaja Narvas. M. Eljas oli J. Hurda korrespondent aastatel 1888-1892. Oma 18. aruandes kirjutas Hurt ühe Eljase saadetise kohta, mis koosnes 48 vanast laulust ehk 838 reast:

Kaunis kogu, mille eest südamest täname. Soovime väga, et lahke saatja veel aega ja mahti võiks leida, lisa korjata ja saata (Postimees 1888, nr 140).

Dietrich Timotheus, mõisavalitseja, viinapõletaja, tööline, kogus nii Jõhvi kui Iisaku rahvapärimust. Ajavahemikus 1888-1904 läkitas ta Hurdale üheksa saadetist. J. Hurt kirjutas oma 43. aruandes laekunud materjali kohta: "Väga ilus kingitus. Oleme südamest tänulised, nimelt ka selle eest, et kohalist murret olete pruukinud." (Postimees 1889, nr 86). 


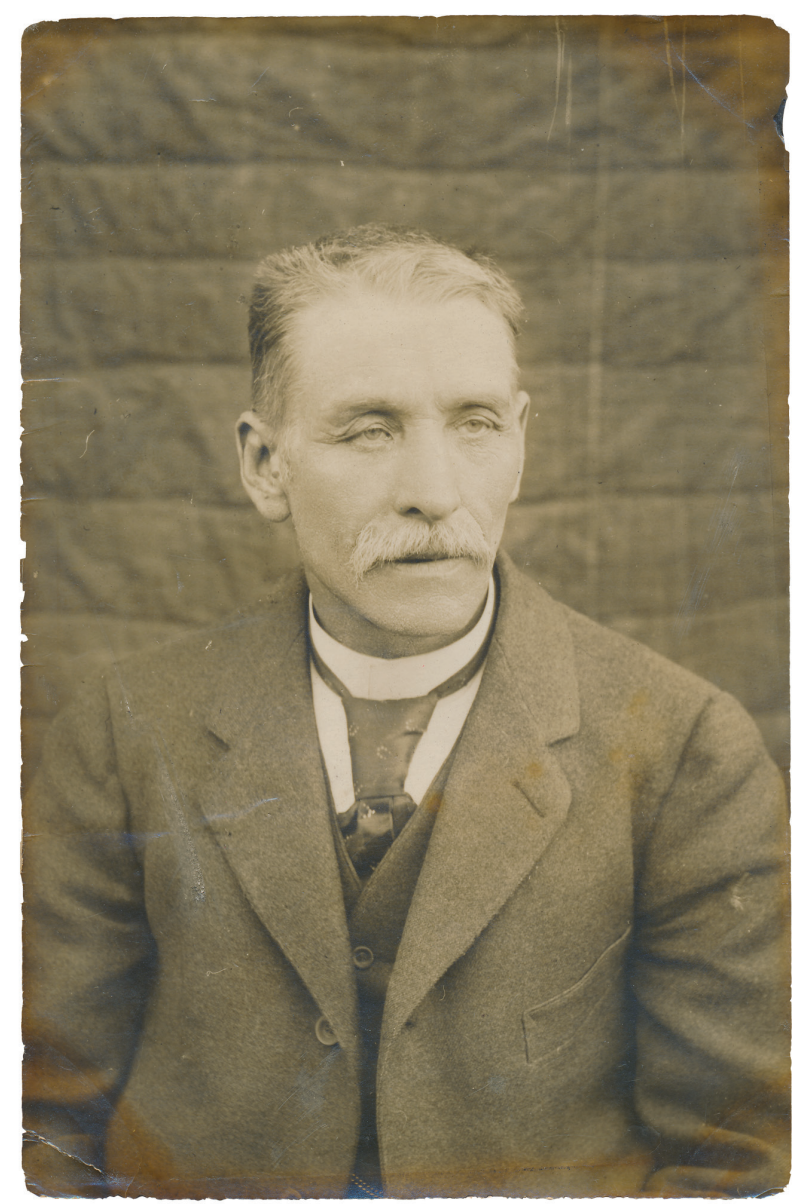

Foto 1. J. Hurda kaastööline Mihkel Eljas Jõhvist. ERA, Foto 5179.

Päite koolmeistri Paulus Paurmanni (hiljem mõisavalitseja ja talunik) rahvajuttude saadetised aastatel 1889-1893 paistavad silma mitmekesise jutuvaramu ja hea murdekeele poolest. Peamiselt saatis Paurmann Jõhvi kihelkonna materjali, aga pani näiteks kirja ka Lüganuse pulmalaule. J. Hurt kiitis tema ülestähendused kauniks ja tuumakaks:

Unustamata töö saab ise töö tegijat jäädavalt kiitma. Aga praegu võtke ka minu südamelikku tänu vastu (Postimees 1891, nr 28).

Väike-Maarjast kogus Hurdale materjali Karl Voldemar Lurich. Rahvaluule suurkoguja Karl Voldemar Rosenstrauch (1877-1919) alustas pärimusainese 


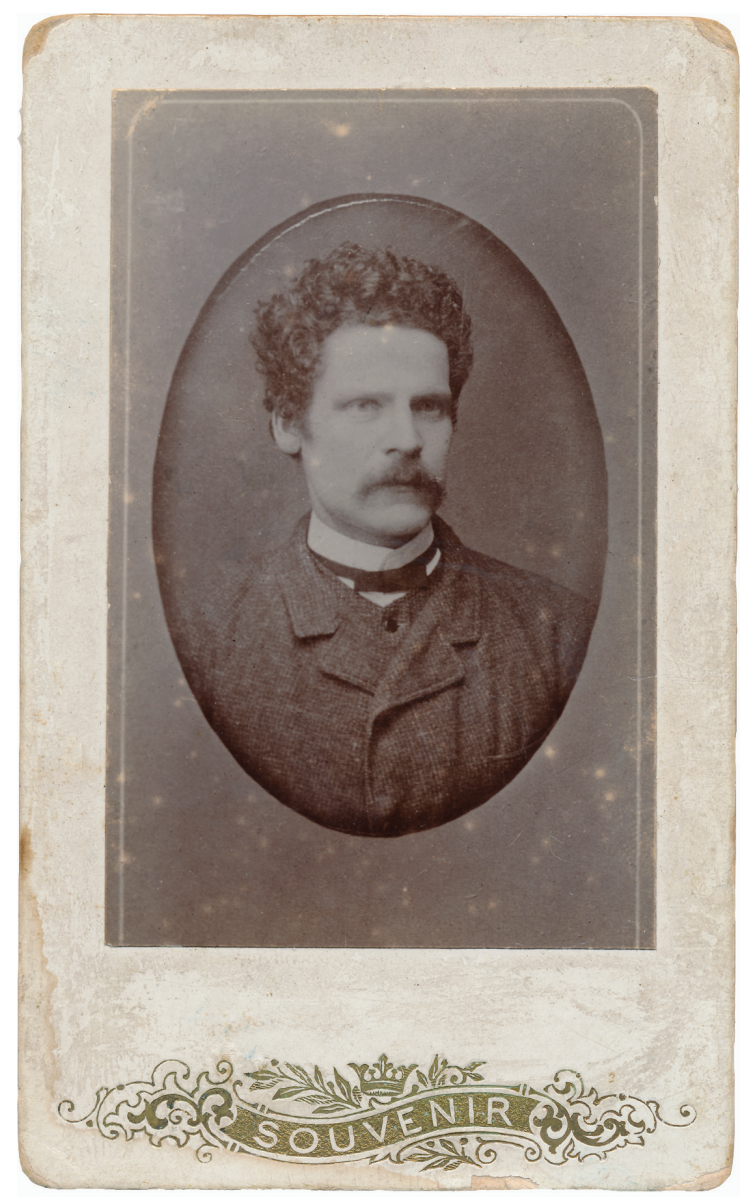

Foto 2. J. Hurda kaastööline Paulus Paurmann Jõhvist. ERA, Foto 5102.

kogumist Väike-Maarja kihelkonnakooli õpilasena, jätkas tööd kooliõpetaja ning viinapõletaja ametis olles. Ta pani Simuna ja Väike-Maarja kihelkonnast kirja üle 700 lehekülje, aastatel 1908-1915 rändas ta laulude kogujana mitmetes Virumaa kihelkondades.

Korduvalt saatsid Haljala rahvaluulet mõisatisleri tütar, hiljem taluperenaine Leena Lepp-Viikmann (Pruul) ning rätsep Viilip Klaas. Haljala kihelkonna suurkoguja Julius Aleksander Rehberg (Reepärg, snd 1873) hakkas rahvaluulet koguma õpilasena Kalevipoja Seltsi koolis. Esimese saadetise - 18 laulu, neiu Liisa Marie Kahtelbergi korjanduse - läkitas ta Hurdale 1889. aastal. Samal aastal kogus ta ka ise mõistatusi, vanasõnu, uskumusteateid, kombes- 


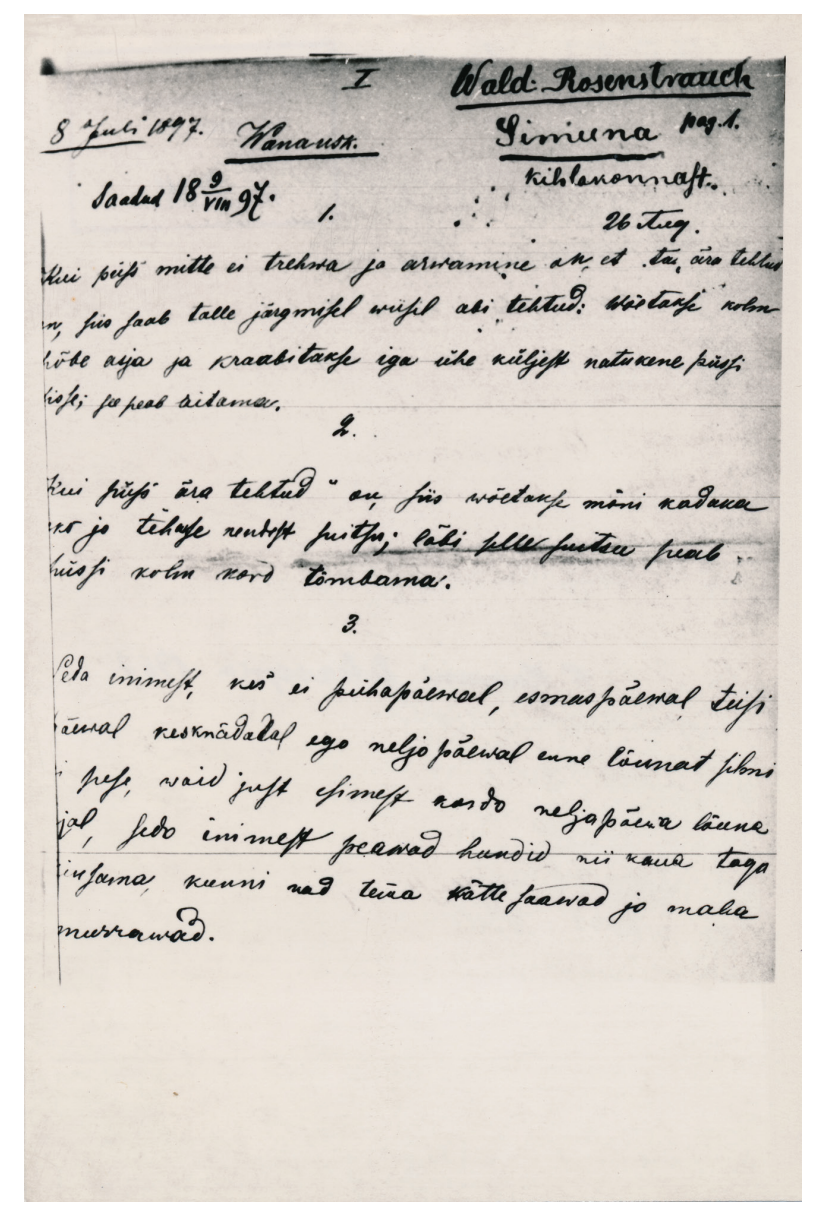

Foto 3. Voldemar Rosenstrauchi saadetis Simuna kihelkonnast. R. Hanseni fotokoopia 1967. ERA, Foto 8124.

tikukirjeldusi jm. Tartus õppimise ajal 22. augustil 1891. aastal kirjutas ta vaimustusega Hurdale:

Rõomuga olen püüdnud korjamisest osa võtta, sest see on töö, mida iga isamaalane tegema peab, kes esivanemaid austab ja nende mälestust kalliks peab. Kiire põllutöö kõrval olen siis võinud nii palju suvel korjata, mida ma nüüd siin Tartus ära saadan. Loodan, et veel edespidi vabal ajal mõndagi terakest unustusest päästa suudan. Soovin südamest asjale hääd edenemist. (RPS I, 3: 93.) 


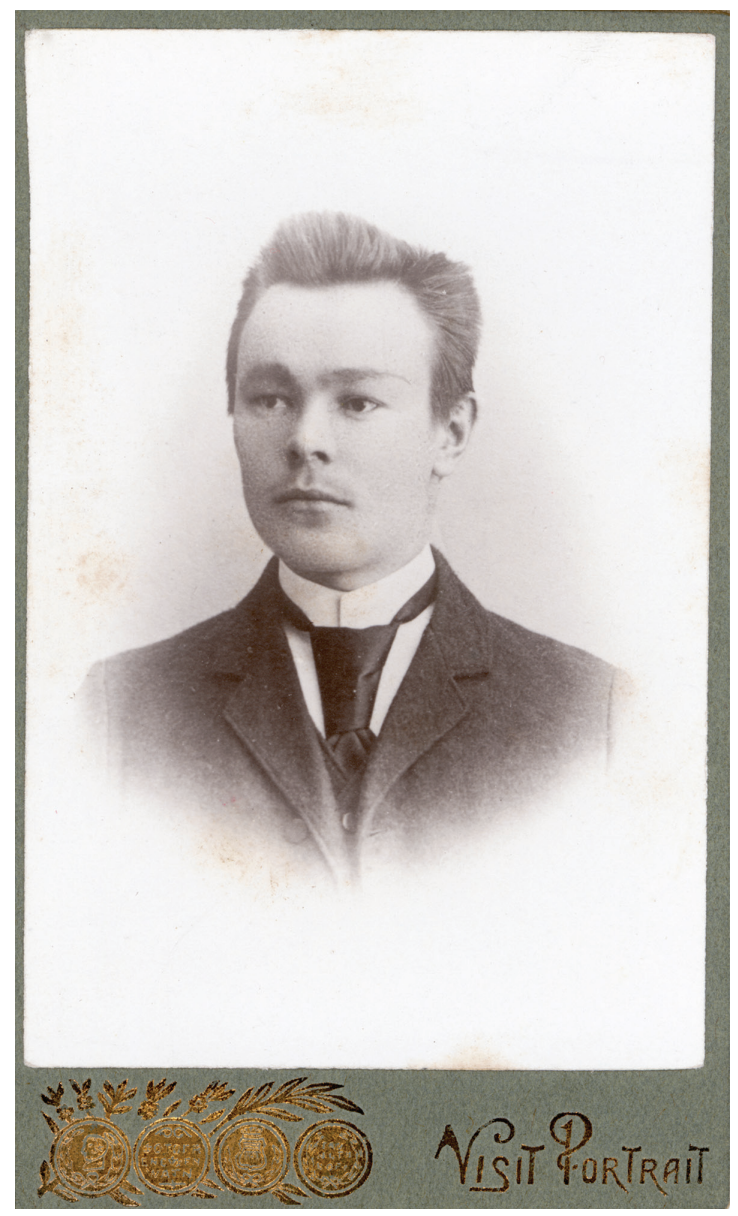

Foto 4. Rahvaluulekoguja Julius Aleksander Rehberg Haljalast 1907. või 1908. a. ERA, Foto 104.

Rehbergi kodukihelkond Haljala oli üks rahvaluulerikkamaid piirkondi. Noormehe Hurdale 7. septembril 1892. a saadetud kiri on juba üksjagu murelikum:

Niisuguseid laulikuid on veel küllalt, kes "päevade kaupa" laulda võiksivad, aga korjajad jäävad ikka enam ja enam leigemaks, uut ergutust oleks vaja. Korjamine oli 1888. ja 89. a. hästi rohke, siis oli asi kõik värske ja nagu uudis, nü̈d hakkab aga vananema. Kraami on küllalt veel rahva seas kogumata, seda tean kindlasti Haljala kihelkonna kohta ütelda. (RPS I, 3: 93.) 
Ajavahemikul 1889-1895 läkitas J. A. Rehberg Hurdale 16 saadetist, sealhulgas $440 \mathrm{lk}$ pärimusmaterjali Haljalast. Korjanduse hinnatavaima osa moodustavad vanad regivärsilised rahvalaulud (Viidalepp 1937: 91-94). Oma korjanduste kohta sai Rehberg Hurdalt kiitvaid hinnanguid, näiteks 13. saadetise puhul:

Teie korjandused käivad ikka kõige paremate hulka, nagu Teie ka oma ustavuse ja hoole poolest esimeses reas seisate (Viidalepp 1937: 94).

Oma kõnes 1896. aastal Riias toimunud muinasaja uurijate kongressil tõi J. Hurt esile just Virumaa rahvaluulekogujaid:

Esiotsas oma saagiga seisab Virumaa ehk Rakvere kreis, kus 15,8\% kõigist materjaalidest kokku korjati. Iseäranis rohkesti saatsivad siit vanavara Veike-Maarja, Jõhvi ja Haljala kihelkond (Hurt 1989: 81).

Hiljem palus Hurt andmeid ka kaastööliste ja kogumistöö enda kohta (vt Olevik 1889, nr 7; 1895, nr 5).

Mitmeid retki eesti rahvaluule kogumiseks tehti 20. sajandi algul Soome Kirjanduse Seltsi (SKS) rahalisel toel. Soovides noori kogujaid abistada, pidas Hurt vajalikuks ise kohalike elanike poole pöörduda:

Alutaguse elanikkudele annan teada, et Soome Kirjanduse Seltsi abiga kaks noort Eesti üliõpilast, Simm ja Haho, sinna maakonda on saadetud, Alutaguse vanu laulusi korjama, iseäranis Iisaku ja Vaivara kihelkonda. Ma palun Eesti perekonde, neid lahkeste vastu võtta ja neile nõu ja teoga abiks olla, et nende töö ja kogumine kaunist vilja võiks kanda. Alutaga on vanavara veel küllalt; aidaku siis kohalised suguvennad ja laulurikkad oed ise, et nende esivanemate mälestused mitte mätaste alla mädanema ei jää, vaid südisti välja kaevatakse ja teaduse valgusesse viiakse (Uus Aeg, nr 68, 1903).

Soome Kirjanduse Seltsi (SKS) abiga kogusid üliõpilased Ants Simm ja Kristjan Haho, viimane oli Viru-Jaagupi kihelkonna Oonurme taluperemehe poeg, Alutagusel vanu laule, iseäranis Iisakus ja Vaivaras. 1903. aastal kogus Jõhvi ja Iisaku kihelkonna materjali Ants Simm. Tema vahendusel jõudis arhiivi ka paarkümmend aastat varem Jõhvi taluperemehe Aleksander Reiska kirja pandud regilaulukogu, käsikiri olnud Iisaku köstri Robert Theodor Hanseni valduses (Tedre 1999: 84). 1904. aastal kogus SKSi stipendiaadina Lüganusel K. Haho.

Soome Kirjanduse Seltsi kogus leidub ka Julius Margi käsikiri 1912. aastast (SKS, Mark), mis sisaldab Haljala kihelkonna rahvalaule ja loitse. J. Mark, sündinud Haljala valla Idavere küla taluperemehe pojana, õppis Helsingi Ülikoolis soome-ugri võrdlevat keeleteadust, rahvaluulet ja sugurahvaste kultuurilugu 
ning talletas SKSi ülesandel oma koduümbruse pärimust. 1913. aasta suvel kogusid Julius Mark ja muusikamees Karl Viljak rahvalaule ja viise. Kokku jäädvustas Mark üle 600 Haljala rahvalaulu.

\section{Matthias Johann Eiseni rahvaluulekogu kujunemine}

Paralleelselt Jakob Hurda kogumistööga, temalt ning soome rahvaluuleteadlaselt Kaarle Krohnilt innustust saanuna alustas rahvaluule kogumist Matthias Johann Eisen (1857-1934), pistes Hurda 1888. aasta kogumisüleskutse teise ja kolmanda osa vahele oma palve - hakata temale mõistatusi saatma. Edaspidi laiendas ta oma kogumistöö Jakob Hurda tööga paralleelselt võistlevaks (Loorits 1938: 146). Eiseni kogu sisaldab ajavahemikus 1880-1934 talletatud pärimusainest.

M. J. Eisen pani Virumaa jutustajatelt ka ise üht-teist kirja, kuid temagi kasutas põhiliselt kaastööliste abi. Mitmed J. Hurda korrespondendina alustanud: N. Otto, M. Sild, A. Valter, J. Lilienbach, K. V. Rosenstrauch, T. Teinmann, L. Lepp-Viikmann jt tegid kaastööd mõlemale suurkogujale. Näiteks esmalt Hurdale materjali saatnud L. Lepp-Viikmann oli üks produktiivsemaid Eiseni korrespondente. Alates 1893. aastast saatis ta viiel korral Haljala kihelkonna laulutekste. Ka Alfred Konstantin Kivi, kooliõpetaja, pärast kunstnik, läkitas korduvalt Rakvere ja Kadrina khk materjali nii Hurdale kui Eisenile.

Osa Eiseni kaastöölisi alustaski temale materjali saatmisest: Vaivara kihelkonnast saatsid Eisenile rahvaluulet Heinrich Masingu õpilased Friedrich, Aleksander ja Eduard Feldbach. Fr. Feldbach oli hiljem kooliõpetaja ja vallakirjutaja Vaivaras, Aleksander kooliõpetaja Vaivaras. Danel Pruhl (Pruul) pani Eiseni jaoks aastatel 1889-1900 kirja nii regilaule kui ka loodushäälte imitatsioone. Viru-Nigula pärimusainest talletas Gustav Johann Jürjev (Kallus), Kadrina kihelkonna materjali saatsid Eisenile Jakob Dania ja Palmse ministeeriumikooli õpilane, sõjaväelane, riigiametnik ning põllumees Anton Merima (Seemann). 1917. aastal saatis Johan Kotli, kes oli Väike-Maarjas köstriks, Eisenile täieliku kogu Väike-Maarja kohanimesid.

Aktiivsed Eiseni kaastöölised olid kohalikud õpilased ning üliõpilased. Rahvaluulematerjali koguti mõnikord ka proseminaritööna. Stipendiaatideks värvati peamiselt rahvaluulekursust kuulavaid üliõpilasi, stipendiumisummad taotles Eisen haridusministeeriumilt. Ajalooüliõpilane Otto (Otu) Liiv, pärastine ajaloolane ja arhivaar, kogus 1924. aastal stipendiaadina Jõhvis ja Iisakus; stipendiaadina kogus pärimusainest veel üliõpilane Karl Martinson. Marta Blum-Koppel kogus Iisaku rahvaluulet, Leida Uustalu pani materjali kirja oma vanematelt. 


\section{Oskar Kallas Eesti Üliõpilaste Seltsi kogumistöö suunajana}

Oskar Kallas, esimene eesti folkloristikadoktor, kes kogus üliõpilasena rahvaluulet Hurda stipendiaadina, oli veendunud, et kirjapanemist väärivad ka rahvaviisid. Muusikalise rahvaloomingu ülesmärkimine aga käis paljudele tolleaegsetele kaastöölistele lihtsalt üle jõu (Tampere 1971: 146). O. Kallas alustas 1904. aastal Eesti Üliõpilaste Seltsi (EÜS) raames ulatuslikku rahvaviiside kogumist (samas: 147). Tema algatusel värvati rahvaviise koguma Peterburi konservatooriumi kasvandikud, kes enamasti liikusid mööda külasid koos üliõpilaste või kooliõpetajate hulgast pärit tekstikirjutajatega. Stipendiaatide reisikulu-raha hankis EÜS annetuste, pidude ja kontsertide korraldamisega. Esialgsed muusika-alased kogumisjuhendid saadi soome muusikateadlaselt Ilmari Krohnilt, mida O. Kallas jt oma kogemustele toetudes täiendasid. Soovitusi jälgida hoolega rahvamuusika olusid ja esitamistavasid võib pidada tolle aja kohta novaatorlikeks (vt Tampere 1971: 149-151). Noortelt kogujatelt nõuti esmakordselt ka kogumispäevikuid, kus nad oma teekonnast ja töös ettetulevatest probleemidest pidid teada andma (vt Tamm 2002: 82-98).

1907. aastal talletas Peeter Süda, tulevane helilooja ja muusikapedagoog, Lüganuse rahvalaule. Tänu Karl Voldemar Rosenstrauchile, kes käis aastatel 1908-1915 koos mõne muusikamehega kogumisretkedel, jäädvustati hulk Virumaa rahvalaule. 1913. aastal kogusid Haljalas laule J. Mark ja Grivingu muusikakooli õpilane K. Viljak, nad panid kirja 358 teksti, 6 mängukirjeldust ja 88 viisi (EÜS X). 1913. aastal kogusid Vaivara kihelkonna laule Peterburi konservatooriumi üliõpilane R. Vilmansen (Villmansen) ja Tartu Ülikooli üliõpilane Hans Kingu. Avinurme vallas sündinud August Sildnik kogus TÜ ajalooteaduskonnas õppimise ajal aastatel 1908 ja 1909 pärimusainest Jõhvi khk külades, temaga töötas koos ka konservatooriumi üliõpilane Paul Penna. August Sildniku matkamärkmetes leiame kogutu kohta statistilised andmed: sõnu umbes 5000 rida, 1 nõiasõna, viisisid 147 umbes 45 lauljalt, ära käidud umbes 500 versta.

Samas on A. Sildnik teinud hinnatavaid tähelepanekuid laulmise ja laulikute kohta:

Peakohaks, kus praegu vanu laulusid lauldakse ja õpitakse, on Illuka nurgas Raudi monopolipoe juures (ennemalt Illuka kõrtsi juures) jüripäeva ajal vananaiste "võitegemine". [---] Lauljaid tuleb ka meeste seas ette, aga $3 / 4$ kõigist, kes meile ette laulsivad, on ikka naised. Noorte seas on vanad regivirsse-laulud ikka naeru all, nii harva tuleb noor inimene ette, kes 
neid oskaks. Selle asemel on Illuka nurgas ja ka mujal suuremalt osalt sentimental armastuselaulud astunud. [---] (EÜS VI 862-863 (1909).)

\section{Walter Andersoni lastefolkloori kogu}

Esimese konkreetsele sihtrühmale suunatud kogumisaktsiooni algatas Tartu Ülikooli professor Walter Anderson. 1922. aasta kevadel tegi ta algust lastelaulude kogumisega, kasutades täiesti uut kogumismeetodit: õpilasi rakendati selgitava loengu järel oma teadmisi kirja panema (Viidalepp 1939: 240-241). Kogumistöös kasutas ta paljude õpetajate, üliõpilaste jt abi, levitades koolides omakoostatud ankeetlehte. Ajavahemikul 1922-1938 vastasid tema ankeetlehtedele 51 Virumaa kooli õpilased. Suuremad saadetised tulid Jõhvi kõrgema algkooli, Tudulinna (juhataja A. Roosvald), Kuremäe, Illuka (õp A. Uffert), Viru-Jaagupi, Simuna, Rakvere II ja III algkooli, Rakvere linna keskkooli ja Väike-Maarja ühisgümnaasiumi õpilastelt.

\section{Kogumistöö Eesti Rahvaluule Arhiivi päevil}

1927. aastal loodud Eesti Rahvaluule Arhiivi (ERA) juhataja Oskar Loorits jätkas Jakob Hurda poolt alustatut. Kavakindlat ja nõudlikku järelkorjandust korraldati oma ametnike ja stipendiaatide, üliõpilaste ja koolide, teiste asutuste ja vabatahtlike kaastööliste abil, võttes eeskujuks nii kogumises kui kogude korraldamises Jakob Hurda "Eesti vanavara" (Loorits 1937a: 17).

Arhiivi kaastööliste abistamiseks ja suunamiseks korraldati õppeseminare, saadeti neile tasuta ERA bülletääni "Rahvapärimuste Selgitaja" (RPS, aastatel 1936-1940 ilmus üheksa numbrit), kus avaldati küsitluskavu, kogumisaruandeid, tutvustati tublimaid rahvaluulekogujaid jne. Temaatilisi küsitluskavu ilmus ka eritrükkidena ning Richard Viidalepp avaldas üksikasjaliku kogumisjuhendi “Juhiseid rahvaluulekogujatele. Mida ja kuidas koguda?" (1936). Mõni aasta hiljem ilmunud trükises "Tööjuhiseid rahvaluulekogujatele" käsitles ta kogumisega seotut veelgi põhjalikumalt (vt Viidalepp 1940: 14-20).

Kaastöölistes püüti folkloorikogumise kõrval äratada huvi ka etnograafilise ainese kogumise vastu (Loorits 1937b: 58), rõhutati esemelise ja vaimse vanavara ühtsust. ERA sai sõnalise vanavara uurimise kõrval ühtlasi rahvaviiside uurimise keskuseks. Ajapikku paranesid tehnilised tingimused helilise vanavara jäädvustamiseks. Eesti Riigi Ringhäälingu, Tallinna Muusika Muuseumi ja Eesti Rahvaluule Arhiivi koostööna salvestati aastail 1936-1938 heliplaatidele 
hulk palu parematelt rahvalaulikutelt, -pillimeestelt ja -jutustajatelt. Algust tehti sotsiaalsete gruppide folkloori kogumisega (nt lastehirmutiste ja mängude kirjapanekud, sõdurilaulud jm).

Kooliõpilased haarati kaasa kogumisaktsioonide abil. 1932.-1933. aastal pandi lastehirmutisi kirja 52 Virumaa koolis. 1934.-1935. aasta rahvamängude kogumise võistlusele tuli Virumaalt kõige suurem saadetis Rakvere Ühisgümnaasiumist, juhendas õpetaja Karl Mihkla. Parimatena märgiti ära õpilased M. Kaevats ja A. Tamvelius, kes kogusid ühiselt 208 mängu, ja Robert Kello. Osalejaid oli veel Jõhvi Ühisgümnaasiumist, Rakvere linna keskkoolist, Nõmmise, Püssi, Aa, Maidla, Annikvere, Laekvere, Selli, Kasaritsa, Kiltsi, Avispea algkoolist jm.

Kohamuistendite kogumise võistlusest 1938.-1939. a võttis Virumaalt osa kõige rohkem koole (41) ja õpilasi (183), ka saadetud materjali hulk oli üks suuremaid - 2232 lk (RPS I, 6: 196; vt ka Kindel 2002). Mahukaim korjandus oli Rakvere gümnaasiumi, progümnaasiumi, reaalkooli ja kaubanduskooli oma, juhendas õpetaja Jaan Meerits, kaasa lõid 36 õpilast, kirjapanekuid kokku 792 lk. Neli J. Meeritsa õpilast tulid auhinnalisele kohale: Robert Kello (II koht), Evald Tarve (III koht), Aadu Allvee ja Taivo Laevastu (ergutuspreemia). Ka Kadrina algkooli poiss Kaljo Viese sai ergutuspreemia.

ERA koosseisulised töötajad Rudolf Põldmäe ja Richard Viidalepp tegid Virumaale mitmeid kogumismatku, kogudes enim rahvatantsude kirjeldusi ning rahvausundilist pärimust. ERA töötaja Paul Ariste kogus 1930. aastal Virumaa materjali koos ERA stipendiaadi Karl Leichteriga, kes noteeris rahvaviise. Üliõpilase-stipendiaadina kogus Mart Tarum pärimusmaterjali lisaku, Jõhvi ja Lüganuse kihelkonnast - kokku 374 lk (RPS I, 1: 16). ERA stipendiaadina kogus Jõhvi, Simuna ja Iisaku materjali Armilda Hallik. Üliõpilane Ludmilla Kraavik pani Vaivarast ERA ülesandel kirja kolm vihutäit kombestikukirjeldusi, mõistatusi, rahvajutte jm. ERA suunas stipendiaate kogumistööle ka kompaktsetele vene aladele. Kirde-Eesti venelaste pärimust kogusid Olga Gromova, Valeria Jegorova jt.

Viljakaim ERA korrespondent oli J. Hurda kaastöölisena alustanud J. A. Reepärg (Rehberg). Pärast 35aastast vaheaega hakkas ta tegema kaastööd ERAle. Ajavahemikul 1932-1937 pani ta Haljala kihelkonnast kirja 1602 lk, sealhulgas 896 regivärsilist rahvalaulu. Reepärg pälvis viiel korral (1936-1940) Vabariigi Presidendi (Riigivanema) auhinna parimaile rahvaluulekogujaile. Ta on kogunud teateid ka J. Hurda korrespondendi Viilip Klaasi kohta ning hankinud ERAle Hermann Läntsi mitmesajaleheküljelise rahvaluulekorjanduse. Presidendi (Riigivanema) autasu pälvis kahel korral leitnant August Haav Rakverest, kes saatis arhiivile eeskätt sõduriluulet, jutluste paroodiaid jms. Auhinna vääriliseks hinnati veel Rakkest pärit Laine Priksi saadetised 
ning Endel Metsa kirjapanekud Jõhvi kihelkonnast. 1936. aasta kogumistöö eest sai II auhinna Meinhard Särg, kes kogus Avinurme vanemailt elanikelt $373 \mathrm{lk}$ pärimusainest: rahvatantsude, tähtpäevade, pühade kirjeldusi, teateid rahvapärastest raviviisidest ja -võtetest, vanasõnu jm. 1936. aasta kogumistöö tulemuste eest leidsid äramärkimist veel Mihkel Sild Avinurmest, kes pani kirja 55 rahvamängu seletust ning Mihkel Tapner Lüganuselt, kes saatis ärakirju laulikutest, rahvajutte, vanasõnu jm. Väike-Maarjast pärit Marsell Rossi kirjapanekud hinnati auhinna vääriliseks 1940. aasta iseseisvuspühal. ERA kogusid täiendasid veel L. Böckler, A. Männiste, T. Pärtel, M. Sepp, J. Tagam, A. Vendt, H. Veski jt.

ERA kogude statistilistest andmetest seisuga 1. aprill 1937 selgub, et Virumaalt oli selleks ajaks talletatud ühtekokku 98123 rahvaluulepala. Piirkondlikult oli esikohal Jõhvi 15544 punktiga (RPS I, 3: 75-76).

\section{Rahvaluule kogumine nõukogude perioodil}

Ühiskonnas toimunud järsud muutused (nõukogude korra kehtestamine, Teine maailmasõda) ja sellega seoses hästitoimiva ERA kollektiivi lagunemine katkestasid mõneks ajaks kogumis- ja uurimistöö järjepidevuse. 1940. aastal jaotati Eesti Rahva Muuseum kaheks iseseisvaks asutuseks: Riiklikuks Etnograafiliseks Muuseumiks ja Riiklikuks Kirjandusmuuseumiks. Esimese moodustasid Eesti Rahva Muuseumi etnograafiline ja kultuurilooline osakond, teise mitmed Eesti Rahva Muuseumi koosseisu kuulunud asutised, sealhulgas Eesti Rahvaluule Arhiiv. Etnograafiline Muuseum esemeliste kogudega jäi Tartu lähedale Raadi mõisa, Riiklik Kirjandusmuuseum sõnavaraliste kogudega endistesse ruumidesse Tartus Aia (nüüd Vanemuise) tänavas. Eesti Rahvaluule Arhiiv nimetati ümber kirjandusmuuseumi rahvaluule osakonnaks. Saksa okupatsiooni perioodil likvideeriti Riiklik Kirjandusmuuseum iseseisva asutusena, rahvaluule osakond liideti Tartu Ülikooli filosoofiateaduskonnaga (Haberman 1949: 5-6). 1943. aasta lõpus ja 1944. aasta algul evakueeriti osa ERA põhikogudest Aru mõisa Elva lähistel, osa Pilistvere kirikusse. Hiljem toimetati originaalmaterjalid edasi Liivi koolimajja Läänemaal. 1944. aasta sügisest hakati kogusid reevakueerima. Viimased folkloorikogud toodi Tartu tagasi 1945. aasta märtsis (Viidalepp 1966: 169-184). Raadi mõis sai 1944. aasta tulekahjus kannatada, maa-ala jäi aastakümneteks Nõukogude Liidu sõjaväe käsutusse, muuseum kolis endisesse kohtumajja Veski tänavas. Sõjajärgselt tegutsesid etnograafiamuuseum ja kirjandusmuuseum kahe eraldi riikliku asutusena. Kogud allutati nõukogude võimu tsensuurile. Rahvaluulekogusid kontrolliti kahel korral, aastatel 1946-1947 ja 1950-1951, anti käsk välja sõeluda riigivastane ja obstsöönne materjal. Seda tehti nii lehtede köitest eemaldami- 
se kui tekstide sodimise-kinnikleepimise teel (Kulasalu 2013: 26-31). Rahvaluule kogumisel seati uueks ülesandeks nõukogude töölis- ja kolhoosifolkloori kogumine, soovitati jälgida klassivõitluse, revolutsioonisündmuste ja Suure Isamaasõja kajastusi folklooris, eelistada ideoloogilisest sobivusest lähtudes teatud ajaloolist ja olustikulist ainest žanripuhastele kunstilistele tekstidele (Oras 2008: 62-63). 1948. aastal anti välja ka ajastuomane "Kogumistöö juhendaja rahvaluule alal" nr 1. 1950. aastate teisel poolel ja 1960. aastate algul kritiseeriti nõukogude folkloori ületähtsustamist ja pöörduti taas klassikalise folkloori poole (samas: 65). 1947. aastal loodi Keele ja Kirjanduse Instituudi (KKI) juurde rahvaluule sektor.

Rahvaluulekogujad tegid sõjajärgseil aastail esmalt lühiajalisi kogumiskäike Ida-Virumaa tööstusrajoonidesse (Kiviõli, Kohtla-Järve). 1950. aastatel asendusid lühiajalised kogumisretked suuremahuliste kindla peatuspaigaga

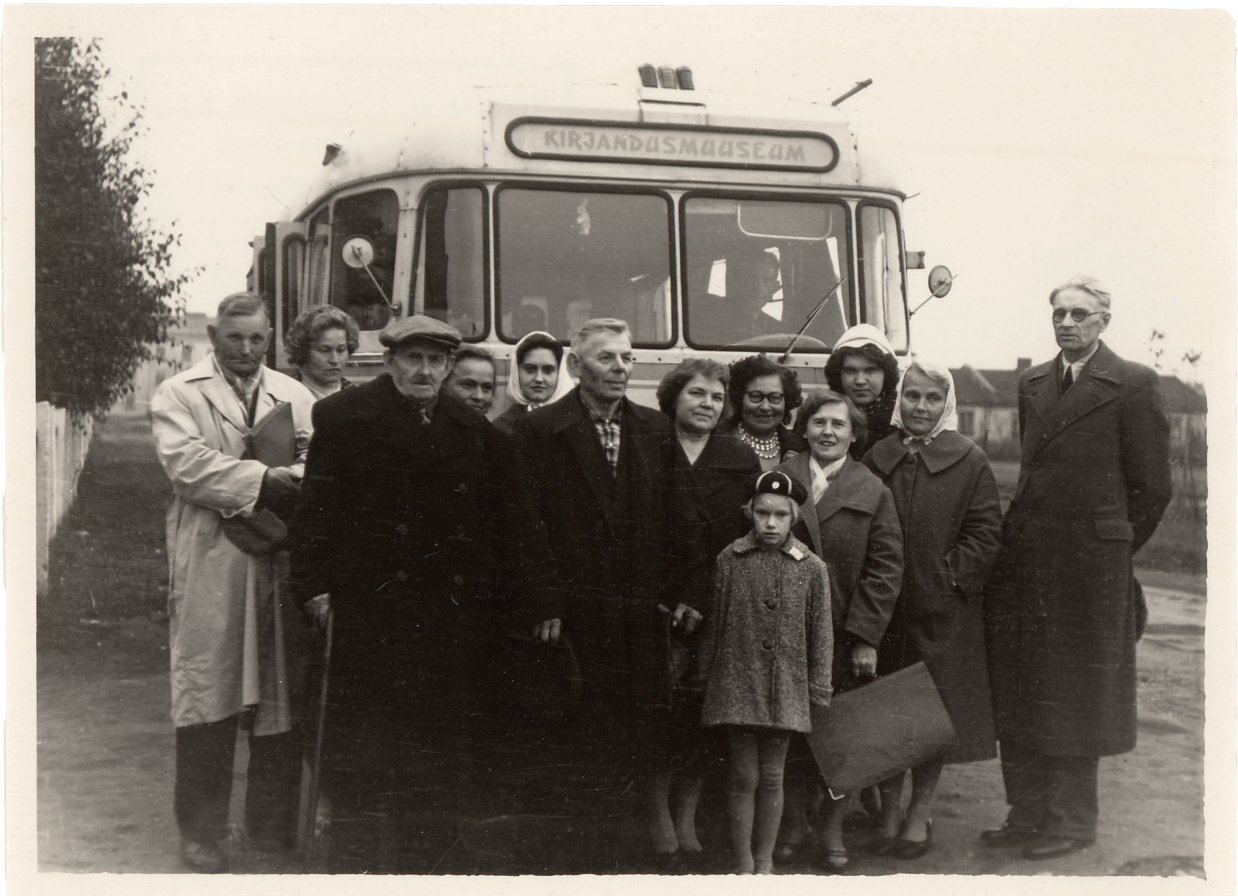

Foto 5. Rahvaluulekogujad-korrespondendid ja rahvaluule osakonna töötajad Kiviõlis. Vasakult: A. Martin, M. Proodel, P. Keimar, E. Tampere, I. Rüütel, M. Kaasik, G. Kallasto, L. Spirka, A. Källo, S. Lätt, A. Vetekaja ja J. Simmo. H. Tampere foto 1962. ERA, Foto 6408. 
ekspeditsioonidega. See andis võimaluse piirkonna tihedamaks läbitöötamiseks, paremate teadjate korduvaks külastuseks, tihedamaks koostööks korrespondentidega (Tampere 1961a: 444). Asutustevahelised kompleksekspeditsioonid - muusikute, etnograafide, murdeuurijate ja folkloristide ühised välitööd, peamiselt aastatel 1948-1951, end ei õigustanud: raske oli jagada tööd, kogutud materjale jm (samas: 441-442). Tihedamaks ja pikaajalisemaks kujunes ühistöö Eesti Raadio töötajatega. Tudengite rahvaluulekogumise juhendamine jäi Tartu Riikliku Ülikooli õlule, nende tarvis anti välja praktilise suunitlusega metoodilisi juhendeid (Kolk \& Laugaste 1969; Laugaste 1970). Virumaa eri piirkondades kogusid tudengid rahvaluulet peamiselt 1950. ja 1960. aastatel.

Takistuseks kogumistöös osutus tehnilise varustuse puudulikkus, mis ei võimaldanud fikseerida rahvapärimust autentses esituses. KKI rahvaluule sektor sai esimese magnetofoni 1949. aastal, kirjandusmuuseumi rahvaluule osakond 1953. aastal. Kogukad salvestusaparaadid olid mõeldud eeskätt statsionaarseks kasutamiseks, paljudes maakohtades puudus elekter. Ajapikku paranes mõnevõrra tehniline varustus, kuid see ei jõudnud kaugeltki nõutavale tasemele. Unikaalse pärimusainese filmimine oli üks nõukogude-perioodi saavutusi, kuid võimalused olid ka siin väga piiratud - filmitava materjali osas tuli teha range valik. Nõukogude folkloristika käsitas rahvaluulena ainult suulist kunstiloomingut, jättes muu traditsioonilise vaimse pärandi, näiteks usundi ja kombestiku, etnograafide uurida ja kirjeldada.

KKI folkloristide põhiliseks kogumisalaks sai Kirde-Eesti. Aastatel 19551958 koguti Richard Viidalepa juhendamisel Jõhvi ja Iisaku pärimusmaterjali, oluliseks eelisteemaks muistendid Kalevipojast. 1960. aastal töötas Viidalepp Narvatagusel, 1961. aastal töötas KKI ekspeditsioonigrupp Vaivara, Jõhvi, Iisaku ja Lüganuse kihelkonna alal. 1962. aastal koguti eeskätt Jõhvi, mõnevõrra ka Lüganuse pärimust. Järelkogumised Lüganuse piirkonnas toimusid 1978. ja 1979. aastal.

Esimene suurem rahvaluuleekspeditsioon Kadrina ja Rakvere khk alal, osalt ka Viru-Jaagupi ja Haljala mail toimus 1969. aastal (Hiiemäe 1972: 38). Kohalikud rahvaluulekogujad Linda Palu ja Vanda Sardma Rakverest olid ekspeditsioonigrupile igati abiks. 1978. aastal töötas rahvaluule osakonna ekspeditsioonigrupp Simuna ja Väike-Maarja, 1984. aastal Viru-Jaagupi kihelkonna alal. Viimases oli välitöö-tegijaile tõhusaks toeks rahvaluule osakonna teenekas korrespondent Viru-Jaagupi pastor Madis Oviir.

Mõned ERA aegsed kaastöölised, nagu Endel Mets, jätkasid pärimusmaterjali kogumist. Lisaks püüti värvata uusi abilisi. Analoogiliselt sõjaeelset kogumistööd käsitleva väljaandega ilmus aastatel 1961-1976 "Rahvapärimuste koguja" (RPK), kokku kümme numbrit. Esinumbris andis rahvaluule osakonna juhataja Herbert Tampere rahvaluulekogujaile asjalikke tööjuhiseid, juhtides 


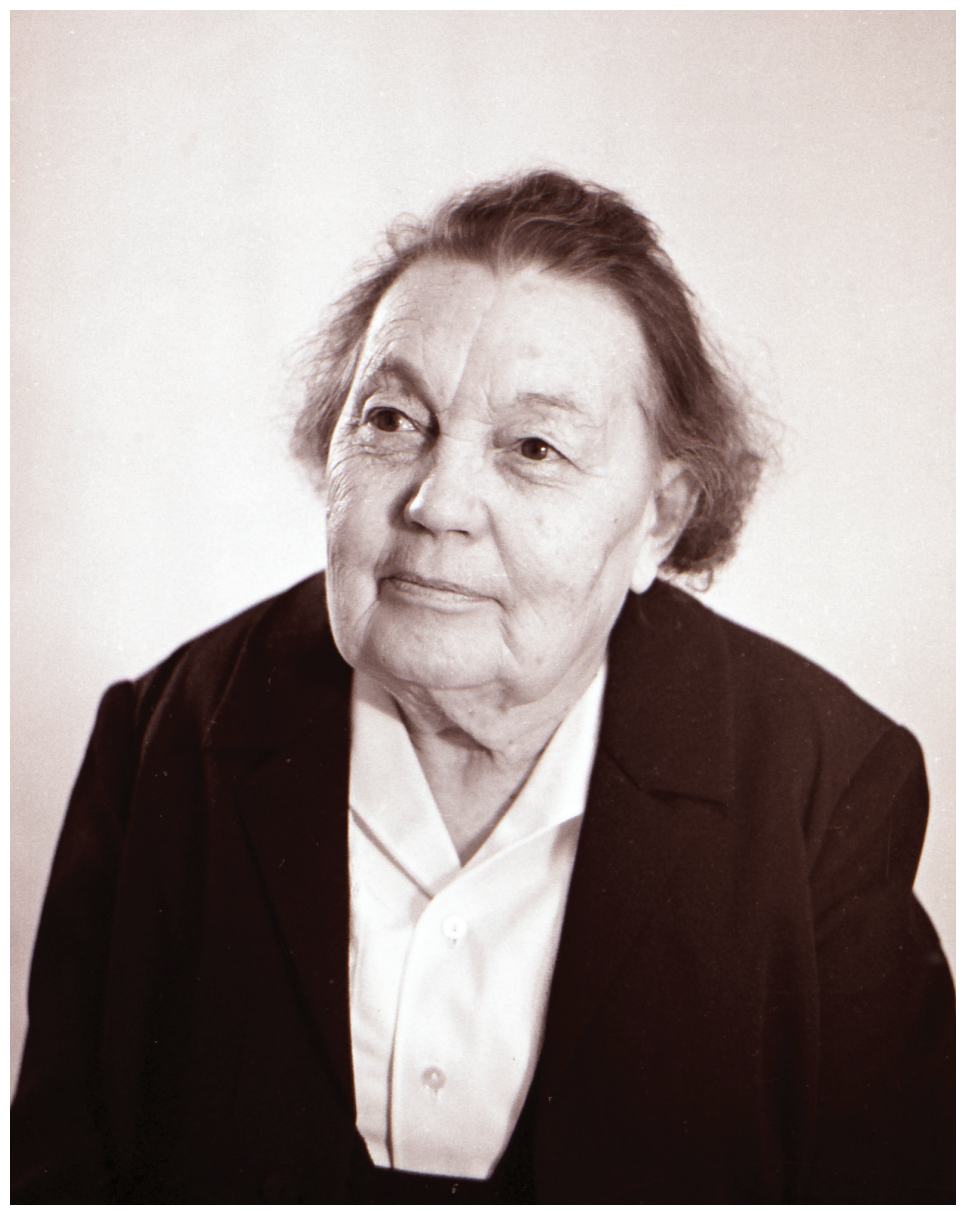

Foto 6. Rahvaluulekoguja Linda Palu Rakverest. E. Kivaste foto 1971. ERA, Foto 9853.

tähelepanu ka rahvaluuleteadete konteksti ja korjanduse vormistamise küsimustele (Tampere 1961b). Suuresti kasutati vanu, ERA aegseid küsitluskavu või seati need uute tegemisel eeskujuks. 1965. aasta suvel viidi läbi rahvaluulekogujate kokkutulek Kadrinas.

Iisaku kihelkonnast pärit Mall Proodel (Hiiemäe) on rahvaluulet kogunud alates 1956. aastast, esmalt arhiivi kaastöölisena, hiljem kutselise folkloristina. Kogutu paistab silma nii hulgalt kui kvaliteedilt.

Üheks võimaluseks uusi kaastöölisi leida ja rahvaluulekogusid täiendada said temaatilised kogumisvõistlused. Näiteks Aino Källo Lüganuselt võttis 1961. aastal osa ajaloolisi sündmusi ja ühiskondlikke vahekordi kajastavate laulude kogumise võistlusest ning jätkas kogumistööd ka hiljem. Temalt on heas 
murdekirjapanekus rahvajutte ning vanasõnu-kõnekäände koos selgitavate andmetega. Esimesed Helene Liivaku kirjapanekud jõudsid muuseumi just A. Källo vahendusel. Edaspidi saatis H. Liivak oma kogutu ise teele. Kirjapanekud on tehtud oma mälu järgi ning küsitletud on ka paljusid ümberkaudseid elanikke.

Seoses rahvaluuleväljaannete koostamise või konkreetse uurimistööga hakati koguma andmeid varasemate korrespondentide, laulikute-jutustajate, muistenditega seotud paikade kohta (vt Tampere 1961a: 443). Selles töös oli palju abi Jõhvi kihelkonnast pärit vanast koolmeistrist ja kodu-uurijast August Martinist (1893-1982), kes sattus Mäetaguse kooli kodulooringi juhendades Päite omaaegse koolmeistri Paulus Paurmanni nimele. Kuna koolis töötas P. Paurmanni sugulane O. Uudemaa, olid head võimalused P. Paurmanni kohta rohkem teada saada. A. Martin märkis:

Meid hakkas paeluma kogu see suur rahvaluulekogumise ajajärk, meist mitte nii kaugest minevikust, 50-70 aastat tagasi (Martin 1961: 56).

August Martin küsitles kohalikke elanikke ning uuris läbi sadu lehekülgi vanu arhiividokumente, et saada andmeid varasemate rahvaluulekogujate ja rahvalaulikute kohta. Oma kogumistöös ettetulevatest raskustest kirjutas ta:

Peab ütlema, et mõnevõrra hiljaks on jäänud andmete kogumine nende virkade Hurda kaastööliste kohta. Nad ise on selles ümbruskonnas viimseni surnud, mõned juba 50-60 aasta eest. Avastadagi on neid tihti raske. Mäetagusele maa-alaliselt lähim Hurda kaastööline oli Mihkel Kriisk Ratvast. Aga uuritaval ajal leidus seal kolm sellenimelist. Kes neist võis see olla? Oli loomulik mõelda, et kaastööliseks oli kõige haritum neist, Simunas V. Nordmanni juures õppinud ja Järvamaal õpetajana töötanud üks Ratva kuulsaid "Simu poisse”. Aga ei. Hurdale kaastööd tegi ta vennapoeg, külakooliharidusega rätsep, hoolas raamatulugeja ja iseõppija (Martin 1961: 61-62).

Tänu A. Martini visadusele on kirjandusmuuseumi rahvaluule osakonnas paljude Hurda ja Eiseni Virumaa-korrespondentide elulood (vt Tupits 2011). Kogumistöö eest määrati A. Martinile mitmel korral preemia.

Kohtla-Järve piirkonnas kerkis esile rida noori võimekaid kogujaid, kelledest kujunes arhiivi kaastööliste võrgustik. 1962. aasta sügisel peeti Kiviõlis edasise koostöö edendamiseks rahvaluule osakonna töötajate ja kohalike kaastööliste ühiskoosolek (Tampere 1968: 14). Mary Kaasik ja Gustav Kallasto Kiviõlist saatsid muuseumile rahvaluulematerjali enam kui kümne aasta vältel. Salme Kiislar Kohtla-Järvelt alustas kogumistööd 1958. aastal. Nooruses taluteenijana ning vanas eas lapsehoidjana puutus ta kokku paljude inimestega. Rohkesti 
on S. Kiislar kirja pannud just ringmängu- ja tantsulaule ning laulnud suure osa nende viisidest ka helilindile. Õpetajast pensionär Hilda Jõulmaa talletas peamiselt Iisaku ja Jõhvi rahvaluulet. Oskar Surva, pärit Mäetaguse vallast Väike-Pungerja külast, hakkas oma kodukoha rahvaluulet kirja panema hiljem Rakvere linnas elades ning talletas ka oma onu, kuulsa nalja- ja laulumehe Muri Mardi lood ja laulud. Iisaku kihelkonnast pärit Edur Maasik alustas oma kogumistööd kodukohast eemal Toris elades. Iisaku materjali, lisaandmetega hästi varustatud, pani ta kirja mälu järgi või tõi kaasa külaskäikudelt kodukohta. Haljala kihelkonnas sündinud Linda Palu töötas õpetajana Virumaal. Kaastööd alustas ta 1961. aastal rahvameditsiini kirjapanekutega, edaspidi talletas ta ka huvitavaid rahvajutte. Viru-Jaagupi mees Hugo Lepiku kohtas mitmeid häid jutustajaid, kes äratasid huvi vanavara vastu. Rakkest pärit Villem Viirmanni kaastööd paistsid silma eeskätt toredate pajatuste poolest. Hiljem külastas ta korduvalt rahvaluule osakonda, et sealt kogumisjuhendeid saada ning rahvalaulude viise helilindistada. Kooliõpetaja ning kodu-uurija Helmut Joonuks Rakkest tegi kaastööd ja osales ka fotovõistlusel "Rahvaluulega seotud kohad ja nähtused”, pälvides II auhinna. Oma kodukoha pärimust talletasid veel A. Aaremäe, H. Kadari, E. Kaljuvee, E. Kasemets, E. Leppik, M. Priimets, E. Tuisk, J. Valdur jt.

\section{Rahvaluule kogumine taastatud Eesti Vabariigis}

Pärimusekogujate varustatus tehnikaga hakkas paranema Eesti Vabariigi taastamise järel tänu kultuuri- ja teadusfondide abile. Aasta-aastalt väheneb arhiivi laekuvate käsikirjaliste materjalide hulk, samas kasvab heli-ja videosalvestuste kogumaht. Eesti Rahvaluule Arhiivi töötajad jätkasid esmalt suuremahuliste piirkondlike välitöödega. 1994. aastal toimusid need Viru-Nigula kihelkonna alal. Nüüdseks on frontaalsest kogumisest suuresti loobutud, välitööd on saanud uurimisprotsessi osaks.

Nõukoguliku ideoloogia surve taandumine 1980. aastate lõpupoole avardas uurimis- ja sellega seoses ka kogumisvaldkondi. Aktuaalseks sai poliitilise pärimuse kogumine ning publitseerimine (Hiiemäe 2002: 281), samuti tegutsevate teadjate: rahvaarstide, ennustajate jt küsitlemine-filmimine (vt Kõiva 1997). Elavnes tänapäevase ainese kogumine: linnajutud, pöidlaküüdilood, nn killud ja paroolid, argiarvamused, ended tänapäeva rahvausundis, tänapäeva mõistatused, rahvakalender jm. Koostöös Soome folkloristidega koguti 1992. aastal Eesti ja Soome koolides kindla metoodika alusel koolipärimust, järgnevatel aastatel koguti Eestis ka venekeelset koolipärimust ning tudengifolkloori. Virumaalt tegid arhiivile kaastööd Iisaku Keskkooli 5.-8. klasside õpilased, keda juhendas 
õpetaja Juta Rääst, ühtekokku pandi kirja 812 lk. Narva Eesti Keskkoolist laekus 69 õpilase kirjapandu, kokku 1391 lk. Venekeelse Narva 11. Keskkooli 7. klasside õpilasi juhendasid õpetajad Tatjana Varutskih, Nadežda Leontjeva ja Tatjana Lebedeva, võistlusel osales 45 õpilast, kirjapanekuid on 596 lk; 1993. aastal ka filmiti Narva kooliõpilasi. 2007. aastal suunatud koolipärimuse kogumise aktsioonil osalesid Virumaalt mitmete gümnaasiumide õpilased.

2013. aastal kultuuripärandi aasta raames korraldatud lastemängude kogumise võistlus oli suunatud eeskätt täiskasvanutele. Paluti saata nii mängukirjeldusi kui ka mälestusi lapsepõlvest, mänge tuli kirjeldada enda mängukogemuse kaudu, et ilmneks ka ajastu mõju laste tegemistele. Kaastöid laekus 77 inimeselt 650 leheküljel, lisaks fotosid, jooniseid, paberlauamänge, pabernukke jm. Kaheteist parema töö seast tõsteti Virumaa kogujatest esile Anne Nurgamaa, Anu Soon, Heinz Valk ja Eha Võso.

Perepärimusse kuuluvat ainest laekus arhiivi kahe temaatiliselt lähedase kogumisaktsiooniga nii Eesti Kultuurkapitali organiseerimisel rahvakultuuriteemaliste koduvideote kogumise (vt Kõiva \& Õunapuu 2001) kui ka ERA kogumisvõistlusega "Eluring" (2001-2002). Virumaalt tegid kaastööd Viktor Sepman Kukruselt, Ellu Leppik ja Väino Tiimus Jõhvist, Anne Nurgamaa Iisakust, Anu Soon Viru-Jaagupist, Selma Vasar Viru-Nigulast, Eduard Leppik Kadrinast jt. Koostöös Fleurop Interflora OÜga korraldatud lillepärimuse kogumisest võtsid virumaalastest osa Selma Vasar ja Heindrich Kruup.

Paiga- ja eneseidentiteedi otsingute ning turismiga seoses tõusis esile kohapärimuse kogumine, seda suuresti kohalike omavalitsuste initsiatiivil. Ka Rakvere Keskkooli kodulooringi liikmed panid kirja kodupaiga muistendeid. 2008. aastal käisid Lahemaa rahvapärimust kogumas Tartu Ülikooli tudengid. Kaasaegsele kohapärimusele ja kohaseostele keskendunud kogumisvõistlusele "Minu maastikud" (2015-2016) laekus 34 Virumaa paikadele keskendunud tööd. Virumaa kogujatest tunnistati II preemia vääriliseks Aino Liivik ja Anne Nurgamaa, Viru Instituudi eripreemia pälvis Heinz Valk. Kalendritähtpäevade tähistamisest Virumaal laekus üle 400 lk kirjapanekuid.

1995. aasta iseseisvuspäevaks taastati Eesti Vabariigi presidendi preemia parematele rahvaluulekogujatele. Selle kõrge tunnustuse on Virumaa kaastöölistest pälvinud Anu Soon 2003. aasta kogumistöö eest ja Eha Võso 2014. aasta eest silmapaistva kodupärimuse jäädvustajana.

\section{Kokkuvõtteks}

Rahvaluule süstemaatiline kogumine on Eestis kestnud umbes 150 aastat. Jakob Hurda, Matthias Johann Eiseni, Oskar Kallase jt algatusest said innus- 
tust paljud eestimaalased ja rahvaluule kogumine on olnud paljude Eestimaa inimeste harrastuseks. See on aidanud läbi aegade tugevdada Eesti identiteeti. Olenemata riigikorrast ja poliitilistest oludest on rahvaluule kogumises nähtud tööd oma kodupaiga ja laiemalt Eesti hüvanguks. Pärast vastava institutsiooni - Eesti Rahvaluule Arhiivi (ERA) loomist 1927. aastal jätkati rahvaluule kogumist oma ametnike ja stipendiaatide, aga ka üliõpilaste, koolide ja vabatahtlike kaastööliste abil. 1940. aastal seoses nõukogude võimu kehtestamisega reorganiseeriti ERA Kirjandusmuuseumi rahvaluule osakonnaks, rahvaluulekogud allutati nõukogude võimu tsensuurile. Teise maailmasõja järel taastati korrespondentide võrgustik. Aja jooksul vähenes ideoloogiline surve rahvapärimusele, mis võimaldas naasta klassikalise folkloori kogumise juurde. Taastatud Eesti Vabariigis on kogumisvaldkonnad oluliselt avardunud ning rahvaluule kogumis- ja uurimistöö on omavahel tihedalt seotud. Virumaalased löövad oma kodupaiga pärimuse jäädvustamisel aktiivselt kaasa.

\section{Kommentaar}

1 Kirjutise valmimist on toetanud Euroopa Liit Euroopa Regionaalarengu Fondi kaudu (Eesti-uuringute Tippkeskus), see on seotud Eesti Haridus- ja Teadusministeeriumi uurimisprojektiga IUT 22-4.

\section{Kirjandus}

Haberman, A. 1949. Riiklik Kirjandusmuuseum teadusliku uurimisbaasina. Riikliku Kirjandusmuuseumi aastaraamat I. Tartu: RK Teaduslik Kirjandus, lk 5-31.

Hiiemäe, Mall 1972. Rahvaluule-ekspeditsioon Rakvere ja Harju rajooni. Rahvapärimuste koguja 8, lk 38-48.

Hiiemäe, Mall 1989. Jakob Hurda rahvaluulekogumise printsiibid tänapäeval. Eesti NSV Teaduste Akadeemia toimetised. Ühiskonnateadused 38, nr 4. Tallinn, lk 310-315.

Hiiemäe, Reet 2002. Uued suunad rahvaluulekogumises alates 1980. aastatest Eesti Rahvaluule Arhiivi laekunud ainese põhjal. Hiiemäe, Mall (koost). Kogumisest uurimiseni. Artikleid Eesti Rahvaluule Arhiivi 75. aastapäevaks. Tartu: Eesti Kirjandusmuuseum, lk 280-293.

Hurt, J[akob] 1888a. Kümnes aruanne Eesti vanavara korjamisest ja keelemurrete uurimisest. 8. septembril 1888. Olevik 37, 12. september, lk 1.

Hurt, J[akob] 1888b. Kaheksastõistkümnes aruanne Eesti vanavara korjamisest ja keelemurrete uurimisest. 1. detsembril 1888. Postimees 140, 8. detsember, lk 1-2.

Hurt, J[akob] 1889. Kaheskümnes neljas aruanne Eesti vanavara korjamisest ja keelemurrete uurimisest. 10 . veebruaril 1889. Olevik 7,13 . veebruar, lk 1. 
Hurt, J[akob] 1889b. Neljaskümmnes kolmas aruanne Eesti vanavara korjamisest ja keelemurrete uurimisest. 27. juulil 1889. Postimees 86, 27. juuli, lk 1; Postimees 88, 5. august, lk 2 .

Hurt, J[akob] 1891. Kuueskümnes üheksas aruanne Eesti vanavara korjamisest ja keelemurrete uurimisest. 20. veebruaril 1891. Postimees 28, 7. märts, lk 3.

Hurt, J[akob] 1895. Saja üheksas aruanne Eesti vanavara korjamisest ja keelemurrete uurimisest. 24. jaanuaril 1889. Olevik 5, 31. jaanuar, lk 3-4.

[Hurt, Jakob 1903. Vanavara korjamine.] Uus Aeg 68, lk 1.

Hurt, Jakob 1989. Mida rahvamälestustest pidada. Artiklite kogumik. Tallinn: Eesti Raamat.

Kindel, Melika 2002. ERA 1938-1939. aasta kohamuistendite võistluskogumine. Hiiemäe, Mall (koost). Kogumisest uurimiseni. Artikleid Eesti Rahvaluule Arhiivi 75. aastapäevaks. Tartu: Eesti Kirjandusmuuseum, lk 100-111.

Kolk, Udo \& Laugaste, Eduard 1969. Rahvaluule välipraktika. 2. tr. Tartu: Tartu Riiklik Ülikool.

Kulasalu, Kaisa 2013. Ropp ja riigivastane: rahvaluulekogude tsenseerimisest Eesti hilisstalinismi perioodil. Magistritöö. Tartu: Tartu Ülikool (http://www.digar.ee/arhiiv/ et/raamatud/42770 - 19. september 2016).

Kõiva, Ottilie-Olga 1985. Kristjan Raud ja rahvaluule. Rahvasuust kirjapanekuni. Uurimusi rahvaluule proosaloomingust ja kogumisloost. Tallinn: Eesti NSV Teaduste Akadeemia, lk 29-39.

Kõiva, Mare 1997. The Transmission of Knowledge among Estonian Witch Doctors. Rüütel, Ingrid \& Kuutma, Kristin (toim). The Family as the Tradition Carrier. Conference Proceedings. Vol 2. NIF Publications No. 31. Tallinn: Nordic Institute of Folklore, lk 77-95.

Kõiva, Mare \& Õunapuu, Piret 2001. Ehe ja alasti rahvakultuur. Sirp, 19. oktoober (http://www.sirp.ee/archive/2001/19.10.01/Film/film1-5.html - 19. september 2016).

Laugaste, Eduard 1952. Fr. R. Kreutzwald folkloristina. Teaduslikud tööd: pühendatud TRÜ 150. aastapäevale. 1802-1952. Tallinn: Eesti Riiklik Kirjastus, lk 43-80.

Laugaste, Eduard 1970. Harjutusmaterjale rahvaluulepraktikaks. Tartu: Tartu Riiklik Ülikool.

Loorits, Oskar 1937a. Uue ülesande haarangul. Rahvapärimuste Selgitaja I, nr 2, lk 17-20.

Loorits, Oskar 1937b. Eesti Rahvaluule Arhiivi 10. aastapäevaks. Rahvapärimuste Selgitaja I, nr 3, lk 57-62.

Loorits, Oskar 1938. Viiskümmend aastat süstemaatset rahvaluule kogumist Eestis. Rahvapärimuste Selgitaja I, nr 5, lk 145-147.

Martin, August 1961. J. Hurda kaastööliste jälgedel. Rahvapärimuste koguja 1, lk 55-68. 
Mirov, Ruth 2009. Rahvaluulekogumine Lüganuse kihelkonnas. Mirov, Ruth \& Tuvi, Edna (koost). Vana Kannel IX. Lüganuse regilaulud. Tartu: EKM Teaduskirjastus, lk 60-84.

Mälk, Vaina 1963. Eesti Kirjameeste Seltsi osa eesti folkloristika arengus. Tallinn: Eesti Riiklik Kirjastus.

Oras, Janika 2008. Viie 20. sajandi naise regilaulumaailm. Arhiivitekstid, kogemused ja mälestused. Tartu: Eesti Kirjandusmuuseumi Teaduskirjastus.

RPK = Rahvapärimuste koguja. Kirjandusmuuseumi kogumistöö juhendaja nr 1-10. 1961-1976. Tartu.

RPS I = Rahvapärimuste Selgitaja I, nr 1-7. Eesti Rahvaluule Arhiivi väljaanne. 19361939. Tartu, 1939.

RPS II = Rahvapärimuste Selgitaja II, nr 8-9. Eesti Rahvaluule Arhiivi väljaanne. Tartu, 1940.

Tamm, Kadri 2002. Oskar Kallase ja Eesti Üliõpilaste Seltsi stipendiaatide reisikirjeldused. Hiiemäe, Mall (koost). Kogumisest uurimiseni. Artikleid Eesti Rahvaluule Arhiivi 75. aastapäevaks. Tartu: Eesti Kirjandusmuuseum, lk 82-98.

Tampere, Herbert 1961a. Rahvaluule-alastest ekspeditsioonidest. Paar sammukest eesti kirjanduse ja rahvaluule uurimise teed. Uurimusi ja materjale II. Tartu, lk 441-446.

Tampere, Herbert 1961b. Üldisi juhiseid rahvapärimuste kogujaile. Rahvapärimuste koguja 1. Tartu: Eesti NSV Teaduste Akadeemia Fr. R. Kreutzwaldi nim. Kirjandusmuuseum, lk 3-9.

Tampere, Herbert 1968. Korrespondentide osast eesti rahvaluule kogumisel. Rahvapärimuste koguja 6. Tartu: Eesti NSV Teaduste Akadeemia Fr. R. Kreutzwaldi nim. Kirjandusmuuseum, lk 3-17.

Tampere, Herbert 1971. Eesti rahvaviiside süstemaatiline kogumine 20. sajandi alguses. Emakeele Seltsi aastaraamat 17. Tallinn: Teaduste Akadeemia Kirjastus, lk 145-157.

Tedre, Ülo 1974. Eesti rahvalaulude kogumine ja publitseerimine. Tedre, Ülo (toim). Eesti rahvalaulud IV köide. Antoloogia. Tallinn: Eesti Raamat, lk 77-87.

Tedre, Ülo 1999. Rahvalaulude kogumisest Jõhvis ja Iisakus. Kokamägi, Hilja \& Tedre, Ülo \& Tuvi, Edna (koost). Vana Kannel VIII. Jõhvi ja Iisaku regilaulud. Tartu: Eesti Keele Instituut, lk 84-116.

Tupits, Ave 2011. August Martin Jakob Hurda kirjasaatjate jälgedel. Lee 17. Eesti Rahva Muuseumi Sõprade Seltsi väljaanne. Tartu, lk 52-60.

Viidalepp, Richard 1937. J. A. Reepärg kui suurkoguja. Rahvapärimuste Selgitaja I, nr 3, lk 91-94.

Viidalepp, Richard 1939. Prof. W. Andersoni lahkumise puhul. Rahvapärimuste Selgitaja I, nr 7, lk 239-241.

Viidalepp, Richard 1940. Tööjuhiseid rahvaluulekogujaile. Eesti Rahvaluule Arhiivi Toimetused 13. Tartu. 
Viidalepp, Richard 1966. Rahvaluulekogude evakueerimine ja reevakueerimine 1944. aastal. Paar sammukest eesti kirjanduse uurimise teed. Uurimusi ja materjale VI. Tallinn: Eesti Raamat, lk 169-184.

Anu Korb - Eesti Kirjandusmuuseumi Eesti Rahvaluule Arhiivi vanemteadur. korb@folklore.ee

\section{Summary}

\section{Folklore collecting and collectors in Virumaa}

Anu Korb

Keywords: collection appeals, folklore collecting, folklore collectors, Jakob Hurt, Virumaa

The article gives an overview of folklore collecting in Estonia throughout times, on the example of the activity of folklore collectors in one of the regions - Virumaa. The collection work grew out of the pursuits of German-origin intellectuals in the early 19th century and, on the initiative of Jakob Hurt, Matthias Johann Eisen, and some others, evolved into an all-Estonian undertaking involving many active people. Irrespective of the state order and hard times, folklore material has consistently been collected in Estonia in collaboration of professionals and voluntary contributors.

Anu Korb is Senior Research Fellow at the Folklore Archives of the Estonian Literary Museum.

korb@folklore.ee 